高分子論文集 (Kobunshi Ronbunshu); Vol. 44, No. 4, pp. 245-249 (Apr., 1987)

\title{
3-メチルチオフェンの電解立合
}

木下 尚*1 ・後藤 邦夫*1 ・曾我 員守*2 ・下間 亘*2 $・$ 森本 和久*2

(受付 1986 年 10 月 31 日・索查終了 1986 年 12 月 22 日)

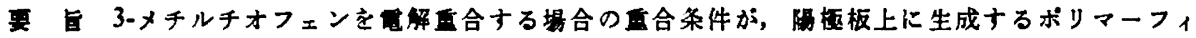
ルム及びその物性に及ぼす影管について検吋した。 その結果, charge density の增加に従い, 膜厚 はほほ exponential に增大することがわかった。また，ガスクロマトグラフィーにより charge densityの堌加に伴5重合被変化を追跡した結果, charge density の增加と比例して重合率も增大す ることがわかった.これらのことから charge density が增ナにつれ，ポリマーのフィルムを形成す

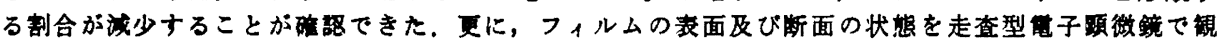
察した。 その結果，重合時のモノマー泿度の高い方がフィルムの梅造がより潄密になっていることが わかった．また，フィルムを調彆ナる時のモノマー㵲度により物性の異なるフィルムが生成すること がわかった。
\end{abstract}

\section{1 棈}

最近，いろいろな種類の道䉓性高分子に関する研究か 数多くなされている. その中です特に, 電解重合法によ り合成されたボリピロールやポリチェニレン（または， ポリチオフェン) などの嫃素五員環式化合物の重合体 は，高算電性以外に空気中での安定性などにすぐれた性 質を示すことから，より高い转電性を持つこれらのポリ マーフィルムの合成が各所で行われている. 中でも，佐 藤らは $510 \mathrm{~S} / \mathrm{cm}$ という高導审性を持つポリ(3-メチ ルチェニレン) フィルムを得たと報告している.

本報では迹電性ばかりでなく，瞙の生成などに同する 基碟的な知見を得るために，3ーメチルチオフェンを電解 重合する時の重合条件が, 陽極板上に生成するポリマー フィルムの膜厚に及ぼす影整などについて追求した。 た、いろいろなそノマー激度において, 電極 $1 \mathrm{~cm}^{2}$ 当た りに通電した電気量 (charge density) と重合率との成 係及び得られたボリマーフィルムの膜厓, 電気伝導度, 密度, 元素組成, 表面及び断面の状態を比較検討した。

\section{2 实涣方法}

\section{1 域菜}

3-メチルチオフェン (Croda Synthetic Chemicals 社

*1 大阪工業大学工学部忘用化学科（亚535 大阪市旭区 大宫 5-16-1)

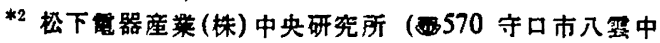
町 3-15)

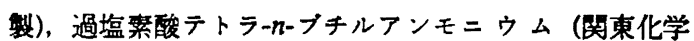
(株)製)、ニトロペンゼン（片山化学工莱(株)製)，ピロ 一ル (東京化成工業 (株) 製) は, 市販の試薬特級品をそ のまま用いた。

\section{2 正合条件}

3ーィチルチオフェン $(0.01 \sim 0.6 \mathrm{M})$ と過塩素酸テト ラークープチルアンモニウム $(0.0005 \sim 0.06 \mathrm{M})$ をニトロ ベンゼン $300 \mathrm{ml}$ に溶解し, 反应系は常に $5 \pm 0.2^{\circ} \mathrm{C}$ に 保った．次いでこの反応系を 30 分間 $2 \mathrm{~m}^{8} / \mathrm{min}$ で空索 ハブルし，その後も空素気流中 $\left(5 \mathrm{~m}^{3} / \mathrm{min}\right)$ で 0.5 $6.0 \mathrm{~mA} / \mathrm{cm}^{2}$ で 20 300 分間通電し, 3-メチルチオフ ェンを電解重合して, ITO (indium-tin oxide) 薄膜カ ラス陽極上に, $\mathrm{ClO}$ イオンがドーピングされたボリ (3-メチルチェニレン) (P3MT-ClO $)$ フィルムを得た. なお，陰極には白金板を用いた，通電䅂了後，ポリマー フィルムを陽極から槑唯し，塩化メチレンで洗浄して室 温で一冝夜減圧乾嬠した.

\section{3 五合卌の決定}

$0.10,0.20,0.40 \mathrm{M}$ の 3-メチルチオフェンをそれぞ れ $n-\mathrm{Bu}_{4} \mathrm{NClO}_{4} 0.02 \mathrm{M}$ ととすに $7.2 \sim 36.0 \mathrm{C} / \mathrm{cm}^{2}$ の charge density で電解重合した. 重合後, 反応溶液を ろ過し，ろ液に基準物筫として一定量のピロールを加 え，末重合の3-メチルチオフェンをガスクロ（(株)島津 製作所製 GAS CHROMATOGRAPH GC-6A 型, SIC 製 Chromatogram Model 7000AS 型) で定田し た. 次にこの未重合モノマー量から反応溶液中に溶存す るポリマーをも含めて，電解重合により消頯された全モ 
ノマー量を算出し、このときの charge density におけ る重合率に換算した，以上の操作からそれぞれのモノマ

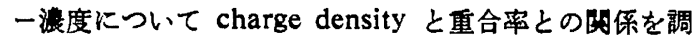
べた.

\subsection{P3MT-ClO4 フィルムの諸物性}

2.4.1 膜原の測定 1 枚のポリマーフィルムにつき 12 点での膜原をデジマチックマイクロメータ（三豊製 作所(株) BMD-25D 型) で测定し，最大值と最小值 を除く 10 点の平均値をそのフィルムの膜厚とした.

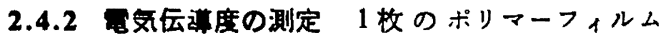
から $0.5 \times 2.0 \mathrm{~cm}$ の試料片を5枚切出し，それぞれ室 温，常圧下において四端子法で電気伝算度を測定し，最 大值と最小值を除く 3 枚の平均値をそのフィルムの電気 伝導度とした。

2.4.3 密度の測定 直接重量測定法を使用した，液 体中での重量測定に当たっては，フィルム表面を十分に 濡らし、かつ、フィルムを膨潤することなく，更に，浸 透しない溶媒を検討した結果，エチレンクリコールの 50\% 水溶液を選び，直換法を用いてポリマーフィルム の体皘を測定し，密度を算出した。

2.4.4 元素租成 4 種類のモノマー浱度で調製した P3MT-ClO、フィルムの元素組成を(株) 柳本製作所製 CHN コーダ MT2 型及び(株)島津製作所製万能有機元 素分析装直で分析した。

2.4.5 表面及ひ断面の状態 表面については，電解 液と接していた表面及び電極と接していた表面を，断面 はフィルムをエポキシ樹脂 (応研商事 (株) EPOK 812）で固め，それを 2 つに折り，それぞれ走查型電子 顕微鏡 (JEOL 製 JSM-35C) で 3000 倍及び 30000 倍 でそれぞれ敘察した。

\section{3 結果及ひ考案}

\section{1 且合条件の变化がポリマーフィルムの厚みに及 はす夥带}

3-メチルチオフェンの電解重合に関する基本的条件と して，モノマー灌度 $0.2 \mathrm{M}$, 支持䉓解質浱度 $0.02 \mathrm{M}$, 重合時間 40 分間, 電流密度 $2.0 \mathrm{~mA} / \mathrm{cm}^{2}$ を採り、こ れらの各素因子の影暗が陽性板上に生成するポリマーフ ィルムの厚みにどのように現れるかを検討した。

3.1.1 モノマー港度の影翠 上記の重合条件のうち,

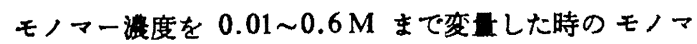
一䈨度と膜厚との関係を Fig. 1 に示す。モノマー淇度 $0.1 \mathrm{M}$ において膜厚は最大值 $16 \mu \mathrm{m}$ となった。 また， $0.05 \mathrm{M}$ より低い港度と $0.6 \mathrm{M}$ より高い灌度の場合， 非常に薄く，かつ脆い〉ィルムしか得られなかった。

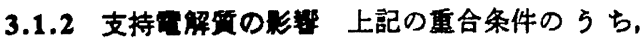
支持電解質 $\left(n-\mathrm{Bu}_{4} \mathrm{NClO}_{4}\right)$ を $0.0005 \sim 0.06 \mathrm{M}$ まで变化 させた時の支持奄解質浱度と膜厚との咸係を Fig. 2 に

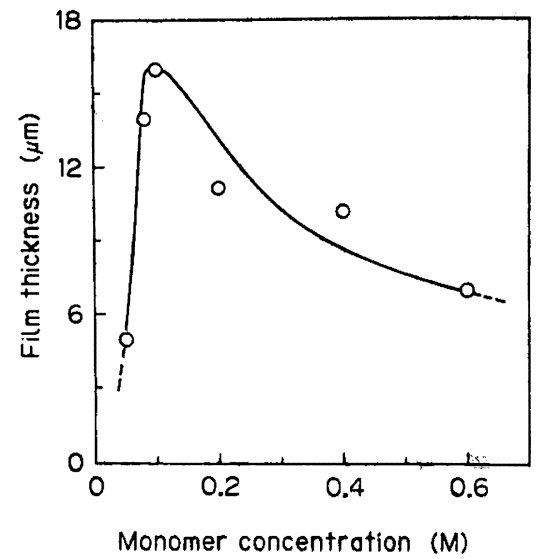

Fig. 1. Relation between monomer concentration and film thickness of P3MT-ClO, films.

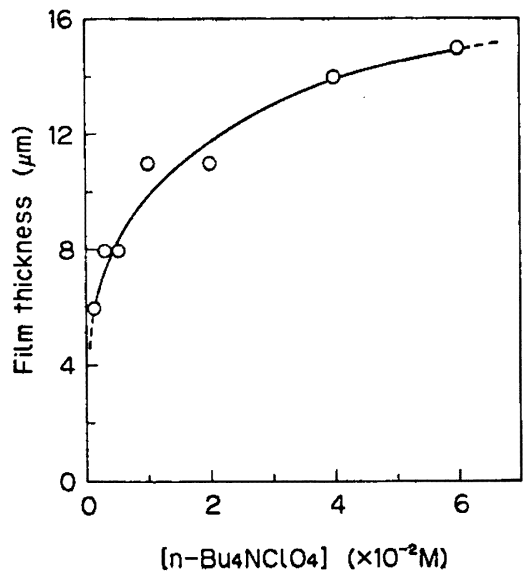

Fig. 2. Relation between supporting electrolyte concentration and film thickness of P3MT-ClO, films.

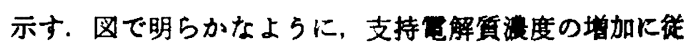
い膜厚も增大したか， $0.01 \mathrm{M}$ 以上に增加しても膜厚の 增大は見られず，特に $0.06 \mathrm{M}$ 以上の高瀑度になると フィルムの強度は逆に減少した.これは，重合と同時に 行われる $\mathrm{ClO}^{\circ}$ ーイオンのドービンクの過鄱が原因する ものと考えられる。

3.1.3 charge density の影照 次に, 重合時間を 20 〜300 分間とし, 電流密度を $0.5 \sim 6.0 \mathrm{~mA} / \mathrm{cm}^{2}$ まて変 化させた時の膜厚への影暗をそれぞれ charge density に換算し, charge density と膜厚との咸係として Fig. 3 に示す。四から明らかなよらに, charge density の 增加に従い，膜厚はほぼ exponential に增大した。す なわち, 膜の生成速度は charge density の增加につれ て，次第に減少することがわかったまま，重合時にビ 


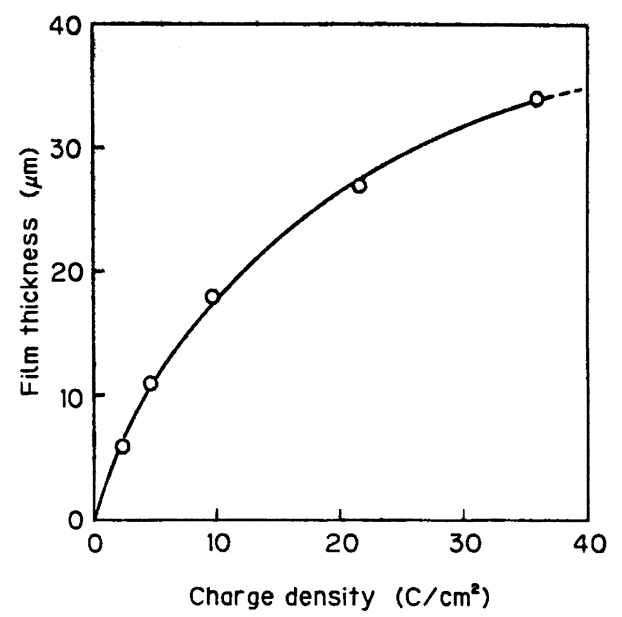

Fig. 3. Relation between charge density and film thickness of P3MT-ClO, films.

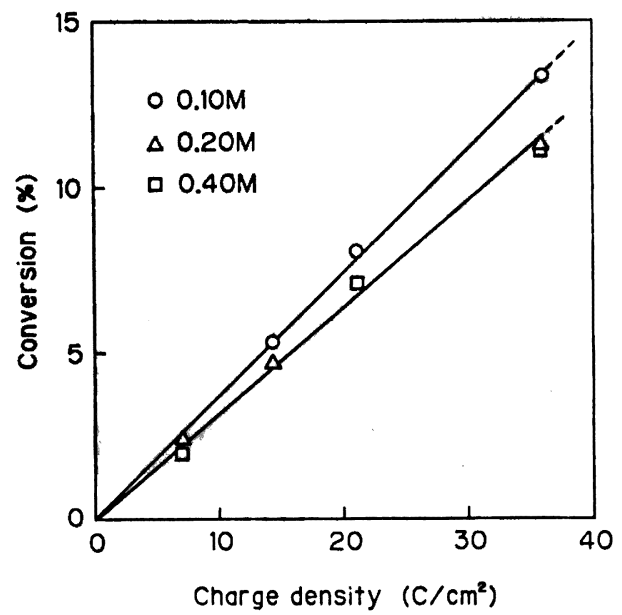

Fig. 4. Relation between charge density and conversion of P3MT-ClO.

Table 1. Physical properties of P3MT-ClO, films prepared by electrochemical polymerization in various monomer concentrations

\begin{tabular}{ccccc}
\hline $\begin{array}{c}\text { Monomer concn. } \\
(\mathrm{M})\end{array}$ & $\begin{array}{c}\text { Thickness } \\
(\mu \mathrm{m})\end{array}$ & $\begin{array}{c}\text { Conductivity } \\
(\mathrm{S} / \mathrm{cm})\end{array}$ & $\begin{array}{c}\text { Density } \\
\left(\mathrm{g} / \mathrm{cm}^{3}\right)\end{array}$ & Empirical formula \\
\hline 0.05 & 5 & 115 & 1.222 & $\mathrm{C}_{6.0} \mathrm{H}_{4.0} \mathrm{~S}_{1.0}\left(\mathrm{ClO}_{4}\right)_{0.21}$ \\
0.10 & 16 & 182 & 1.402 & $\mathrm{C}_{6.0} \mathrm{H}_{4.0} \mathrm{~S}_{1.0}\left(\mathrm{ClO}_{4}\right)_{0.24}$ \\
0.20 & 11 & 93 & 1.429 & $\mathrm{C}_{5.0} \mathrm{H}_{4.2} \mathrm{~S}_{0.08}\left(\mathrm{ClO}_{4}\right)_{0.23}$ \\
0.40 & 10 & 10 & 1.405 & $\mathrm{C}_{6.0} \mathrm{~W}_{4.2} \mathrm{~S}_{1.0}\left(\mathrm{ClO}_{4}\right)_{0.18}$ \\
\hline
\end{tabular}

一カーの壁面にポリマーが付着したり, 重合後の反応溶 液中からポリマーを沈殿回収できたことから，電解重合 法で重合したポリマーのすべてが陽極板上にフィルムと して形成されるのではないことが確認できた．このと き，溶液中に溶解していだポリマーの分子量を浸透圧法 で求めたところ，67800 であることがわかった。

\section{2 charge density と重合事との関係}

モノマー浱度 $0.10,0.20,0.40 \mathrm{M}$ で電解重合した 時の charge density と重合率との関保を Fig. 4 に示 す. 因から明らかなよらに, charge density の增加に 徒い重合率す增大し、これらが比例関係にあることがわ かった. このことと 3.1.3 で示した charge density と 膜厚との関係で, charge density の增加に従い膜厚は 注ぽ exponential に增大することから，3-イチルチオフ ェンを電解重合する場合，通電する電気量が大きくなる に從いボリマー全体の量はそれと比例して增大寸るか， フィルム形成に関与するポリマーの割合は高密度域でむ しろ減少するむのと思われる.

\subsection{P3MT-CIO, フィルムの請物性}

$0.05,0.10,0.20,0.40 \mathrm{M}$ のモノマー濃度で調製し たポリマーフィルムの膜厚, 電気伝尊度, 密度, 元素組
成をそれぞれ Table 1 に示す。またそれぞれのポリマ 一フィルムの表面（電解液側及び電極側）と断面の SEM 写真をそれぞれ Fig. 5，6 に示寸.

3.3.1 瞙厚 膜厚はモノマー瀑度 $0.10 \mathrm{M}$ において 最大值 $16 \mu \mathrm{m}$ となり, それより高い濃度 $0.20,0.40 \mathrm{M}$ ではそれぞれ $11 ， 10 \mu \mathrm{m}$ であった。一方，低い濃度 $0.05 \mathrm{M}$ では，電極表面に薄く弱いフィルムが付着する だけで膜厚は $5 \mu \mathrm{m}$ であった。

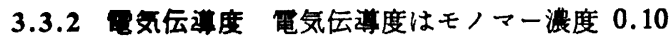
$\mathrm{M}$ のときに最大値 $182 \mathrm{~S} / \mathrm{cm}$ となり，0.05, $0.20,0.40$

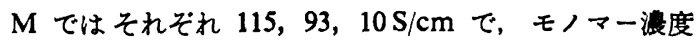
$0.10 \mathrm{M}$ から重合して得たフィルムは厚みにおいてす。 電気伝導度に捣いても実験中最大值を示した。

3.3.3 密度 モノマー湦度 $0.05,0.10,0.20,0.40$ $\mathrm{M}$ で得たポリマーフィルムの密度は，それぞれ 1.222 , $1.402,1.429,1.405 \mathrm{~g} / \mathrm{cm}^{3}$ であった.

3.3.4 元洯組成 極板上に生成したフィルムの元素 組成を Table 1 亿示す.なお，過塩素酸イオンはフィ ルム中で $\mathrm{ClO}_{4}$ ーイオンという化学種で存在することが 堀田ら²により報告されており， $\mathrm{ClO}_{4}^{2}$ イオンの含有量 は塩素の元素分析結果に基づいて決定した。 その結果, 


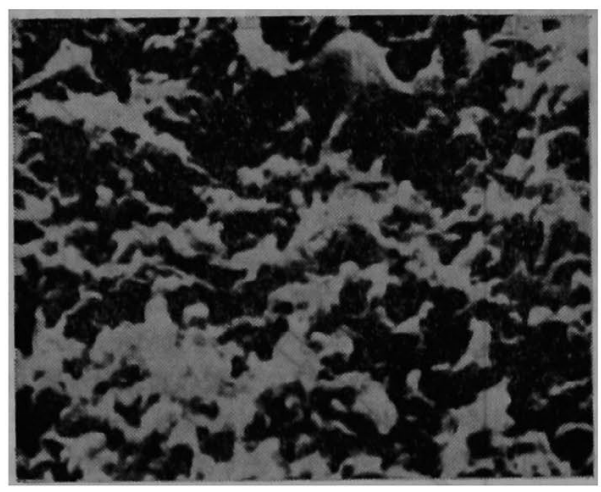

(a)

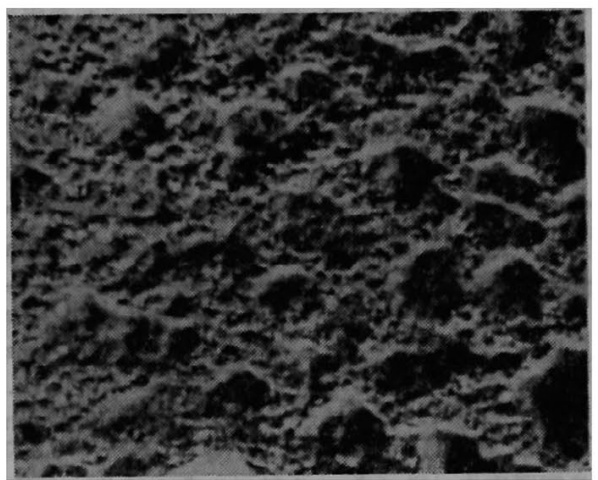

(c)

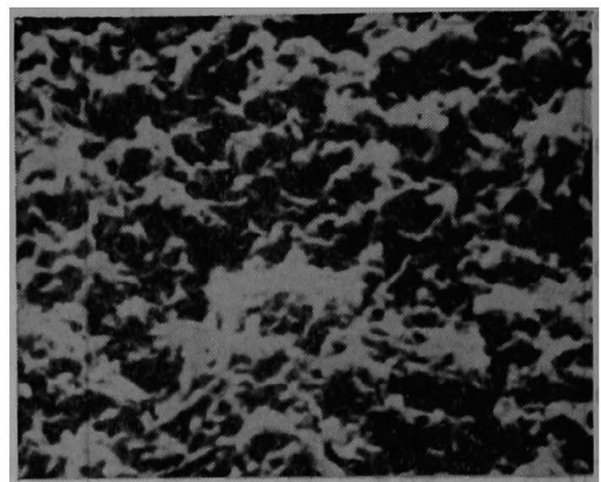

(b)

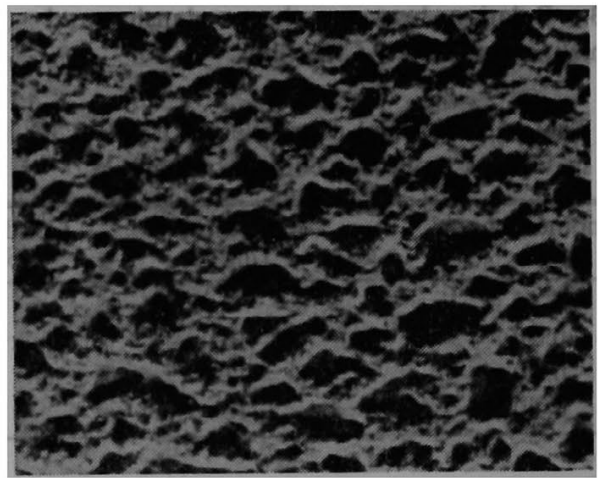

(d)

\section{$1 \mu \mathrm{m}$}

Fig. 5. Electron micrographs of the surface of $\mathrm{P}^{\mathrm{MMT}}-\mathrm{ClO}_{4}$ films. (a) $0.1 \mathrm{M}$, Electrolytic solution side $(\times 30,000)$, (b) $0.20 \mathrm{M}$, Electrolytic solution side $(\times 30,000)$, (c) $0.10 \mathrm{M}$, Electrode side $(\times 30,000)$, (d) $0.20 \mathrm{M}$, Electrode side $(\times 30,000)$.

4 種のフィルムはチオフェン環 1 個当たり $0.18 \sim 0.24$ 個の $\mathrm{ClO}_{4}$-イオンを含有するものと推定される.

3.3.5 表面及ひ断面の SEM 写真 Fig. 5 の SEM 写真から明らかなよらに, 重合の進行する䉓解花と接し ていた表面では，モ/マー濃度の高い方がより政密なフ ィルムの構造を持つことがわかった．しかし，電極と接 していた表面では，どのフィルムもよく似た状態を示し ており，ITO 薄膜ガラス電極表面の転写が原因とみら れる凹凸が観察された。 また，Fig. 6 の SEM 写真で も明らかなように, 断面の状態も電解液側表面と同様に モノマー濃度の高い方かより緻密なフィルムの構造を持 つことがかかった.

更に，同じモノマー濃度で調製したポりマーフィルム の場合, 電気伝導度はドーパント含有量により決定され
ることが堀田ら2゙により報告されているが，モノマー浱 度 $0.10 \mathrm{M}$ で調製したフィルムと $0.20 \mathrm{M} て ゙$ 調製した フィルムの元素組成を比較すると，それぞれチオフェン 環 1 個当たり $0.24 ， 0.23$ 個のドーパントを含有してお り，ほぼ同量であるにもかかわらず，電気伝㫷度は $0.10 \mathrm{M}$ の方が 2 倍大きくなっている. また，SEM 写 真で観察したフィルム表面及び断面の状態です，モノマ 一濃度の高い方がより縹密なフィルムの構造を持ち，密 度も高いことが明らかになったが，電気伝導度とフィル ムの密度との間には必ずしも比例的な関係は見いだせな かった，一方, $0.40 \mathrm{M}$ から得られたフィルムの密度か $0.20 \mathrm{M}$ のそれより小さい值を示すのは，ドーバント含 有量が少ないためと考えられる，また，0.05 M から得 られたフィルムの密度が他のものと比べて極端に小さい 


\section{3ーメチルチオフェンの電解重合}

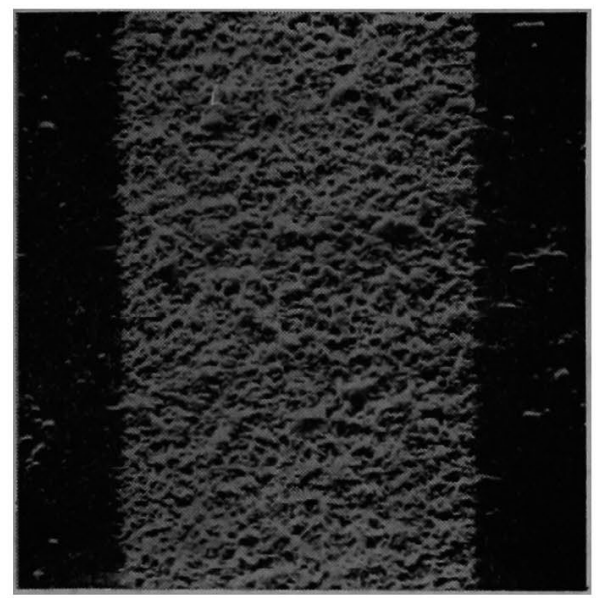

(a)

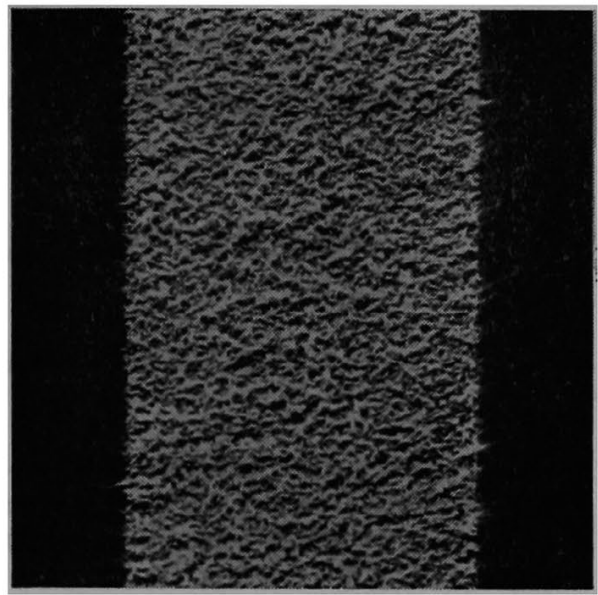

(b)

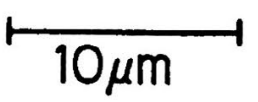

Fig. 6. Electron micrographs of the cross section of $\mathrm{P} 3 \mathrm{MT}-\mathrm{ClO}$, films. (a) $0.10 \mathrm{M}(\times 3,000)$, (b) $0.20 \mathrm{M}(\times 3,000)$.

のは,このフィルムの密度漬に当たって, 陽極板上に わずかに付着した亟く薄く弱いフィルムを用いたため に, 密度测定が困難であり必ずしも正確な值にならなか ったと考えられる.これらのことから，電解重合法によ って陽極板上に生成するポリマーフィルムは，モノマー 瀑度によって異なった性質を有するものといえよう．

終わりに，本研究を進めるに当たり，SEM 写真を撮 影して下さった(株)松下テクノリサーチの河内秀景主任 技師ならびに稲里幸子社員に深く感謝いたします。ま た, 試料調製及び物性測定に御協力下さった大阪工業大
学応用化学科の上田一樹君ならびに玉井紀之君に心から 感謝いたします。

文献

1) 佐藤正昭, 田中進, 㷌山享二, 第 21 回高分 子研究成果発表会资料, 1 (1986).

2) 堀田収, 保阪富治, 曾我宜守, 竹谷 誠, 古 曳重美, 下間 亘, 日本化学会誌, 3, 365 (1986).

\section{Electrochemical Polymerization of 3-Methylthiophene}

Hisashi Kinoshita*1, Kunio Goto*1, Mamoru SogA*2, Wataru Shimotsuma*2, and Kazuhisa Morimoto*2 *1 Osaka Institute of Technology (5-16-1, Omiya, Asahi-ku, Osaka,535 Japan)

*2Central Research Laboratories, Matsushita Electric Indutrial Co., Ltd. (3-15, Yakumo-nakamachi, Moriguchishi, Osaka, 570 Japan)

The polymer film and its physical properties are influenced by the polymerization conditions when poly (3-methylthienylene) is prepared by electrochemical polymerization. The thickness of the polymer film which formed upon the electrode was exponentially increased with an increase of the charge density. Unpolymerized monomer was analyzed by gas chromatography. The conversion was defined. This increased with an increase of the charge density, while the extent of film formation decreased. The surface and the cross section of the film were observed by SEM. The film prepared at a lower concentration of monomer had higher porosity. Physical properties of the film were affected by the initial concentration of monomer.

KEY WORDS Poly(3-methylthienylene) / Electrochemical Polymerization / Conductive Polymer /

(Received Octorber 31, 1986: Accepted December 22, 1986)

[Kobunshi Ronbunshu, 44 (4), 245-249 (1987)] 